\title{
IDEOLOGY, NEOLIBERALISM AND SUSTAINABLE DEVELOPMENT
}

\author{
Juan Cervantes*
}

Bauhaus-Universität Weimar, Weimar, Germany

\begin{abstract}
This paper examines the interactions between issues such as ideology, neoliberalism, institution-building and sustainable development. The central focus of the paper is to demonstrate that the neoliberalism hasn't succeeded just because it is an economic strategy which better serves the interests of the capitalist class (though it must be stressed that this fact has obviously contributed) but mainly because it has been promoted as an attractive economic strategy by respected, well organized and transnationalized institutions all around the globe, and understand the reasons behind this institutional support. After reviewing the interrelationships between the Bretton-Woods institutions and their relationship with the concepts of neoliberalism and sustainable development, the paper concludes claiming that the so-called neoliberal ideology operates behind the discourses of growth, progress and sustainability and that it is in charge of softening domination by diffusing legitimating ideas and granting concessions to subordinate forces, thus implying significations and values that transcend the possible manipulation of the world as an object.
\end{abstract}

Key words: capitalism, economic policy, neoliberalism, consumerism, sustainable development, ideology.

Article Info: Manuscript Received: July 22, 2012; Revised: October 30, 2013; Accepted: November 11, 2013; Online: November $20,2013$.

\section{Introduction}

Five decades ago, based on the ideological zoneregimes created by post-war treaties, another cultural and spatial order emerged as Western capitalism faced Eastern communism. It must be underscored that, since the fall of the Berlin Wall, communism has crumbled as a system, and our current world is built on those ruins.

Therefore, since the end of the Cold War, few places in the globe have held to traditional formulas of authority. The Cold War opened the door for further-accelerated industrial development, which has not only contributed to weakening the nation-state further, but has also given rise to further liberalization, often accompanied by privatization. Moreover, corporate capitalism is now ubiquitous, disseminating a message of ridicule of any alternative to the dominant market in the name of freedom. So-called 'liberal democracy' is spreading across the planet. It involves privatization, either eliminating unprofitable activities or generating income; it deregulates in order to foster markets; it restructures its public ser-

\footnotetext{
* Correspondence address:

Address: Bauhaus-Universität Weimar, Professur Sozialwissenschaftliche Stadtforschung, Belvederer Allee 4, 99423 Weimar,

Germany.

Telephone: +49 (0) 3086459180

Email: juan.cervantes@uni-weimar.de
}

vices in order to lower operating costs. It could, therefore, be assumed that the corporate capitalist model prioritizes market-disciplinary solutions to regulatory problems.

These capitalist strategies are hidden behind democratic and technological solutions, which are often misread in triumphalist terms as the "coherent and directional history of mankind", as stated by Francis Fukuyama (1992, p89). We can observe that this notion is also demonstrated whenever a scientific issue solved through human intervention using fossil fuels or manufactured materials is conventionally viewed as a success of management and a contribution to economic good, when it could otherwise be easily considered as a hazard to sustainability. In this sense, it should be outlined that a distinctive feature of this ideology is the massive use of fossil fuels. By the beginning of the last century, the upswing of the automobile as the dominant mean of transport had begun in the USA. Although in the beginning only the bourgeoisie could afford them, a variety of the changes brought on by the industrial revolution made production cheaper. This, of course, influenced the eventual prices of the cars and, in turn, made it possible for middle class families to afford this mean of transport as well. The stock market crash of 1929 also favoured the abandonment of public transport, 
coupled with the bourgeoisie's lack of interest in it. Insofar as its use was generalized, automobiles were favoured by the governments, which in turn had invested a considerable amount of money in the construction of road infrastructure. In this way, this process ran parallel to the decline of railways as well as to the substitution of coal with oil. Thence it could be assumed that these changes favoured an accelerated accumulation of capital in both the automotive and oil industries.

Fukuyama's vision of accumulation without end synthesizes the direction towards which the whole planet is headed.

It should also be noted that this interpretation of the world has a direct relationship to the 'ideology of progress': namely, the assumption that the domination of nature through technological resources - developed, in turn, by the sciences - is the key to the well-being of humanity. This viewpoint has its roots in the 17th century and emerged with Bacon and Descartes. The idea of economic growth promised an expansion of human wellbeing insofar as the development of productive forces continued to grow. It could be said that this ideology of growth gained prominence with Adam Smith at a time when the accelerated growth of the industrial revolution was taking place in Great Britain.

One of the objectives of this paper is to demonstrate that the sustainable development is headed towards nothing different than a sustainable neoliberalism. The main objective, however, is to show that the neoliberalism hasn't succeeded just because it is an economic strategy which better serves the interests of the capitalist class (though it must be stressed that this fact has obviously contributed) but mainly because it has been promoted as an attractive economic strategy by respected, well organized and transnationalized institutions all around the globe.

The question at this point is, how took place the legitimisation of such a sectional economic strategy? The answer is developed through analyses dealing with issues such as ideology, neoliberalism, institution-building, sustainable development and the interactions between them.

In the first part the terms of Ideology and neoliberalism are analysed in a brief theoretical and historical framework, this serves as a basis to the further development of the paper, which then deals in connecting the aforementioned terms with the concept of sustainable development and the hegemonicideological backup that the concept has received. All of these trying to contribute to the understanding of the ways in which this scheme has been constructed historically, which remains somewhat overlooked in the literature of neoliberalism and sustainable development.

\section{Ideology}

According to Corominas (2001) the ethimological origin of the word ideology comes from the greek $\varepsilon^{\prime} \mid \delta \omega \lambda$ ov 'image'; which in turn comes from í $\delta \varepsilon \dot{\alpha} \alpha$ 'appearance' (often used to describe the ideal appearance of a determined object), derived from í $\delta \varepsilon i ́ \gamma$ which is synonym of the latín videre; the word enjoyed a somewhat semi-polar use in the Middle Ages, judging by the fairly frequent use of it to describe rocks shaped in the form of familiar objects.

Ideology, according to Audi (1999) is a term, which is usually accompanied by a derogatory connotation, it is often used to refer to opposed (or different at some degree) political views.

In the early twentieth century, Leo Strauss, the political philosopher, held the view that political philosophy had been replaced in the twentieth century by ideology. "political philosophy has been degraded into merely another ideology" (Emberley\&Cooper, 2004, pxiii). The political philosophy was the study of the nature and justification of coercive institutions; this mean that such institutions used (at least sometimes) the force or threats of force in order to control the behaviour of its members. The justification for such behaviour lays in the fact that the aforementioned institutions wanted to demonstrate that the authorities were entitled to obedience; and that the correlative obedience was a duty of its members, in other words, that such institutions had legitimate authority over its members.

The term ideology was used by Marx when referring to the false consciousness shared by the members of a particular social class.

It must be outlined that for Marx, the effects on natural processes (e.g., conversion of nature into objects of labour and their products into commodities, as well as the generalized exchange among these products in function of its value) are generated by the surplus-production process, which is based in the social relations of production, thereby causing a confrontation between wage labour and capital. This is why Marx did not conceived the functioning of the economy as a relation between things, but sought to account for the social structure that transforms the nature in objects of labour (in natural use values capable of being incorporated into the aforementioned surplus-production process), which is in general terms what Marx called commodity fetishism. Then it is clear, that for the capital the nature is nothing but a requirement towards the creation of surplus, in this sense, any little thing that exists in nature is prone to be turned into surplus.

Nature in the form of the means of production becomes part of the capitalist process, a mean towards surplus value production, and hence becomes alien to 
labour because it is employed as a mean of exploitation and extraction of surplus. Hence the human being in capitalism is not only estranged from production (because it doesn't own the products it produces), but is also estranged from nature, which serves capitalist interests: Machinery "in itself it is a victory of man over the forces of Nature, but in the hands of capital, makes man the slave of those forces" (Marx, 1985, p 465) as cited in (Fuchs, 2006, p22).

With commodity fetishism, Marx lays bare the ideological effect produced by the capitalist process of production, in which the reality appears as a relation between things. That is why Marx, in the Grundrisse (Marx/Engels, 1983, p604-605), said:

"The coarse materialism of the economists, which deals with the social relations of production of men and the determinations that things receive as soon as they are subsumed under these relations, as if there were natural properties of the aforementioned things, is also a crude idealism, and even fetishism, because it attributes social relations to things as if they were immanent determinations to them, thus mystifying such relationships.”

\section{Neoliberalism}

Regarding neoliberalism, it must be outlined that the concept has become one of the most used words in politic, social and economic fields, which are trying to analyse not just the extents of the actual economic crisis but also the extent in which the social life has been submitted to the requirements of the free market. So it could be assumed that the concept represents the continuation of an economic phenomenon of remarkable historical meaning founded in an ideological construct of progress.

As ideology it is based on the denial of state interventionism, which advocates the free market and competition as the supreme criteria of economic and social organization, linked to the "consumerism" as an intrinsic element of the logic of capitalist production. (Mardones\&Aguirre, 1989)

Some of the main neoliberal authors such as Hayek, Friedman and Popper characterized his own position simply as liberalism, even though there are essential differences between classical liberalism and contemporary neoliberalism, for example in his conception of ethics and politics. (Vergara, 1984)

The current phase of economic globalization has come to be characterized increasingly not by free competition as idealized in neoclassical theory, but by oligopolistic neoliberalism: oligopoly and protection for the strong and a socialization of their risks, market discipline for the weak." (Gill, 1995, p405)

Duménil and Levy stated that modern capitalism, or "contemporary capitalism" as they denominated it, has different periods and therefore articulates itself differently each time, being neoliberalism its latest period, so, it could be said that it is the current representation of capitalism. '...neoliberalism is a social order aimed at the generation of income for the upper income brackets, not investment in production nor, even less, social progress' (2011, p1, p22)

According to Brenner, Peck \& Theodore (2011) neoliberalism has become the dominant process of regulatory restructuring, they stress the strong influence that the market exercises over this process and therefore signal that it could be denominated as 'marketization' or 'commodification', however they opted for the neoliberalization term to highlight the similarities between the prevailing patterns of regulatory restructuring after the seventies and earlier classical liberalization project, associated with the British imperialism of the late nineteenth and early twentieth century, which is where the roots of the neoliberalism came from. Therefore they stated that neoliberalism is historically specific.

Regarding this issue, it could be helpful to cite David Harvey which in an interview explained the difference between liberalism and neoliberalism in the following way (Boulet, 2013):

\footnotetext{
“...it began to crystallize in the mid-seventies and was much more centralized, to the extent that the power had shifted significantly in favour of the financial sector, which since then became the main agent (at least at some extent). That was not the case with the liberalism. In the era of liberalism it was understood that the financial sector should ease the productive activity, so its role was more that of a lubricant than an engine of the accumulation process."
}

From the ideological perspective it should be stressed that contemporary neoliberalism has essential differences with the classical liberalism, in this sense neoliberalism could be considered as the negation of classical liberalism because it implies a social Darwinism totally opposed to the ideals, motivations and economic and social objectives of the authors of the British political economy, such as Adam Smith, Thomas Malthus and Stuart Mill, whose liberalism included a competitive humanist ideal consistent with the revolutionary ideals of the rising bourgeoisie and with an ethical conception which expressed the concern of the classical economists on the social problem generated by the industrial revolution.

The incomplete, discontinuous or differential character of the projects designed to enforce market rules, or its coexistence with other potentially antagonistic projects (eg, social democracy) does not provide a sufficient basis to question its neoliberalizing dimensions, therefore it could be assumed that the neoliberalism is a hybrid process. 
The neoliberalism has been articulated in an irregular way in different spaces, territories and scales as result of continuous confrontations between specific neoliberalization projects and the always evolving political and institutional arrangements, therefore it could be assumed that the uneven development is not a temporary condition, product of an incomplete institutionalization of the neoliberalism but instead it is one of its constituent features.

Brenner, Peck \& Theodore argue that the neoliberalism process is a tendency because its consequences have been quite enduring and affect many political-institutional levels.

The commercialization and commodification processes taking place in capitalism (or the efforts to spread the "market discipline") are always mediated by state institutions in several policy areas of production (e.g., labour, money, social protection, education, housing, land, environment, etc.). For this reason, Brenner, Peck \& Theodore (2011) conceived neoliberalization as a particular form of regulatory reorganization: it involves the rearrangement of institutionalized modes of governance which are collectively binding and, more generally, the relationship between the state and the economy in order to impose, distribute or consolidate commodified and commercialized social ways of life. That's why they denominated the neoliberalization process as a regulatory restructuring subjected to market discipline.

Following the analyses done to the constituent elements of neoliberalism, Brenner, Peck \& Theodore (2011, p21) formulated the following definition:

“...the neoliberalism supposes a historically specific, hybrid and unevenly developed tendency of regulatory restructuring subjected to market discipline.”

It must be outlined a David Harvey's (2005, p3) sentence which denotes the ideological construct of the neoliberal strategy when he states that neoliberalism has become hegemonic as a mode of dis- course. It has pervasive effects on ways of thought to the point where it has become incorporated into the commonsense way many of us interpret, live in, and understand the world.

Furthermore, the advocates of the neoliberal strategy now occupy positions of considerable influence in education (universities and many 'think tanks'), in the media, in corporate boardrooms and financial institutions, in key state institutions (treasury departments, central banks), and also in those international institutions such as the International Monetary Fund (IMF), the World Bank, and the World Trade Organization (WTO) that regulate global finance and trade.

\section{The Bretton-Woods Conference}

It is fundamental to understand the reasons why the neoliberal project has been supported and promoted by the institutions mentioned above, this analysis will reveal the functioning of some of these organizations, looking to expose the ideology behind it, which serves as an engine to the neoliberal machinery of the system in which we live immersed.

It must be stressed the fact that the aforementioned organizations were created in the post-war agreements reached at 'The United Nations Monetary and Financial Conference', held from the ist to the 22nd of July of 1944 at Bretton-Woods, New Hampshire, United States, and therefore commonly known as the Bretton-Woods Conference. The objective of the aforementioned Conference was to establish the rules to regulate the international monetary and financial order after the World War II in the understanding that these agreements would promote economic growth and would be helpful towards avoid a global economic depression similar to that of 1930.

John Maynard Keynes -representing the United Kingdom and its desire for economic stability- and Harry Dexter White -representing the USA and its desire for free trade- laid the groundwork for the economic planning in the post-war period, one of the immediate objectives was the reconstruction of the war-damaged industrial nations.

Keynes proposed the creation of a global common unit of currency called bancor, arguing that it was necessary as a global accepted vehicle for investment, trade, and payments in the foreseen new global economic system along with two new global institutions - a world central bank and an International Clearing Union- which would be in charge of the regulation of the international trade with strong incentives for every country in order to avoid substantial trade deficits or surpluses. As outlined by Keynes, countries with payment surpluses should increase their imports from the deficit countries and thereby create foreign trade equilibrium. (ECA, 2011, p3)

It should be outlined that White objected the creation of the bancor, request that was granted at the conference, mainly due to the fact that the devastated Britain had no choice but to ask for aid, making the US dollar the global 'reserve currency'. In the same direction White also influenced the management system of the aforementioned organizations proposed by Keynes. So the International Monetary Fund (IMF) and the International Bank for Reconstruction and Development (IBRD, now the World Bank) were created according the North American perspective (in fact both institutions have its headquarters in Washington). Thus there were no incentives for States to avoid a large trade surplus and therefore the burden 
for correcting a trade imbalance would continue to fall only on the deficit countries, precisely what Keynes tried to avoid.

As the US dollar took the role of the 'global reserve currency' it took also the role that the gold standard has played before in the international financial system. (Prestowitz, 2003) The US decided to set up a system of fixed exchange rates managed by these newly created international institutions to link the dollar to gold -at the rate of $\$ 35$ per ounce of gold- so any government and central bank would be able to exchange dollars for gold. In this way the dollar was the currency with the most purchasing power and the only one that was backed by gold, so it could be said that this is how the dollar became effectively the global currency.

Through that, the 'Invisible Hand' of Adam Smith turned out to be a 'tangible' hand which, since then has had special consideration with the transnational corporations, the only beneficiaries of the global economic integration agreements signed in Bretton Woods.

Now, after this brief resume about the Bretton Woods Conference and directing it towards the objective of the paper, the question is:

\section{Which is the relationship (if any) between the Bretton-Woods Institutions and the Sustainable Development?}

In order to answer this question, it is necessary to go back and analyse the evolution of the aforementioned institutions and the way in which its direction has been reoriented as well as the reasons behind these reorientations.

The main tasks of the early World Bank established in Washington and run by Wall Street bankers- were, to reconstruct the old colonial infrastructure for its main clients, which were, New York and London based Banks, so it is clear that in those early times reducing poverty was never on the agenda of the Bank.

How then, the World Bank decided to direct its efforts towards 'Working for a World Free of Poverty' as its motto states it, and what's most important, why?

In this direction I would like to cite Goldman which paragraph about the Bank's ways to open up new horizons for intervention could be very helpful, because it makes reference to the ideological construct in which the bank is based, in an effort to find legitimation.

"The Bank has never had trouble raising money; its trouble has always been in lending it. To drum up continuous business in a circumspect world, the Bank de- pends on its capacity to generate the ideas of new global problems as well as on its own global expertise, new mechanisms for intervention as well as new reasons for countries to borrow, new development subjects and subjectivities as well as new forms of its own legitimation." (Goldman, 2005, p34)

It must be outlined that the Bank has been backed up by the Global hegemony since its foundation, and according to Babb and Chorev (2009, p461) hegemony, in the classical Gramscian sense, is a form of domination that is maintained not simply through coercion or force, as neo-realists would argue, but also through consent, achieved by means of moral and intellectual leadership and material compromises (Gramsci, 1971). For neo-Gramscian international relations scholars, an hegemonic world order relies partly on the material capabilities of a dominant state-including its military might and its economic power. They continue to explain that hegemony also depends on dominant ideas and collective images, and on institutions, which "reflect the power relations prevailing at the point of origin and tend, at least initially, to encourage collective images consistent with these power relations" (Cox, 2006, p363).

Regarding the dependence of the maintenance of hegemony through institutions, it should be noted that in the fifties and sixties, the Bank focused primarily on training small group of elites, some of whom became prime ministers, ministry heads, and senior Bank and IMF staff. So by the eighties, they had an organized and well-financed institutional architecture that was already in place, plenty of 'trans-nationalized' people, norms and beliefs, as well as agencies and institutions well situated to participate, this could explain why some government agencies and civil servants can participate in a potentially lucrative neoliberal agenda even while their peers in government and society do not, and thence this fact could be considered as the reason of the quick expansion of the neoliberal economic ideology all around the world. (Goldman, 2005, p32-34) In this sense, the institutions were essential for the construction, maintenance and expansion of the neoliberal ideology because they help soften domination by diffusing legitimating ideas and granting concessions to subordinate forces.

It could be considered that the idea of fighting poverty with massive capital interventions emerged from the historical conjuncture which took place at the seventies when the U.S. hegemony besides being in a recession (grounded in the accelerated inflation produced by the Vietnam War) was being challenged by Europe, Japan, and the oil-producing OPEC nations in one side, and by revolutionary insurgent movements throughout the South, on the other side. A moment of which Robert McNamara -President of the Bank at the time- took advance of, in order to 
harness the large surpluses of capital in the North and the economic calamities of the South into a new development regime that helped to turn the World Bank into a global defender of the world's poor.

However, it must be outlined that just a decade after the "McNamara revolution," the contradictions inherent in large-scale development lending and policy making became manifest as economies crashed, and therefore the institutionalized hegemony of neoliberalism staggered because the Bank was no longer considered an expert offering technical advice at a distance, instead it became the focus of scorn, anger, and frustration.

\section{A new cornerstone: The relationship between the Bretton Woods Institutions and Sustainable Development.}

According to Goldman (2005, p94-98) the Bank, besides being considered blameful of reduced public spending; mass unemployment; currency collapse; rising prices for food, fuel, and other goods; and falling wages and export prices, was also seen as the main responsible for the destruction of huge wetland areas and tropical forest in Indonesia, and also the main responsible for the deforestation, river contamination and even the death of forest-dwelling indigenous people as consequence of the development of highways, dams and the implementation of industrial agriculture in regions such as Brazil, Philippines, India and Thailand. While this happened some capital-poor states were dealing with serious financial issues -which were grounded in the export-oriented Industrialization model, imposed by the Bank's structural adjustments - the Bank lent them dollar-based capital towards the development of export quality commodities, the expected income would be used to pay back the debt and reinvest in the society - as it was presented by the Bank and thence as it was considered by the borrowing countries - however, the overabundance of the capital lent by the World Bank was focused in the production of determined commodities - oils, grains, cotton, rubber - this in turn caused a dramatic fall in the prices of such commodities. (George\&Sabelli, 1994)

All of these events provoked the organization of campaigns against the negative social and environmental effects that the bank unleashed and thence people manifested its discontent in massive protests in Thailand, Indonesia, India and Brazil. It should be outlined that the protest against the Polonoroeste Highway in Brazil even reached the US Congress, where speakers representing the indigenous groups testified the destructive effects of the project -which was presented by the World Bank as a leading example of sustainable development- this in turn originated reactions among members of the US Congress, some of them threatened with a suspension of the support to the multilateral development banks, some others became resolute to discipline the World Bank.

So, facing criticism and confronted with the social and ecological devastation - unleashed from the implementation of its projects and policies - the Bank considered the need for a reorientation in order to calm the members of the US Congress and at the same time to appease the global society, in this way the environment was introduced as the cornerstone of development.

The respectful attitude that the Bank adopted regarding the environment could be seen as a tactical movement because it is grounded in the fact that this kind of behaviour would help them to gain back the confidence of the northern policy makers, in this sense, and citing Goldman (Goldman, 2005, p97) "the Bank imposed on its borrowers 'environmental adjustment' policies throughout the 1990s (often in concert with its fiscal structural adjustment policies), which pressed governments into creating cookiecutter-like environmental protection agencies; redrafting forestry, land, and water laws; establishing national environmental policy and research institutes; and training a cadre of professionals to carry out environmental reforms"

The Bank approves loans for infrastructure projects and as a precondition is that natural assets and resources are privatized, the beneficiaries of the Bank's loans are the transnational corporations who are in control of such assets and resources and not the native inhabitants- in this direction it should be remarked that satisfying an IMF conditionality is typically a mandate for assistance by the World Bank and other international agencies. In this way the control over a national economy by Bretton Woods is virtually complete.

\section{Sustainable development: A neoliberal ideological construct?}

I would like to cite Eric Swyngedouw's definition of sustainability as an empty signifier, because it would be helpful to understand the reasons why this concept is used as an ideological catalyser of opposed social processes.

"Sustainability is the empty signifier par excellence. It refers to everything and nothing at the same time. Its prophylactic qualities can only be suggested through metaphors. Hence the proliferations of terms like 'sustainable cities', 'sustainable planning', 'sustainable development', 'sustainable forestry', 'sustainable transport', 'sustainable regions', 'sustainable communities', 'sustainable harvesting', 'sustainable use (of any) resources', 'sustainable housing', 'sustainable growth', 'sustainable policies', etc. The winks to 'sustainability' in itself guarantee that issues related with nature and the 
environment are serious and that public offices take into account our fears and therefore that the 'security of the nation' is in good hands." (Swyngedouw, 2011, p41).

Through this sentence it could be assumed that the neoliberal ideology, which operates behind the discourse of sustainability, implies significations and values that transcend the possible manipulation of the world as an object.

As it was the case with the World Bank, the concern for the environment is nowadays one of the global goals, and in this sense the concept 'sustainable development' is applied in any imaginable way, it must be outlined that the meaning of such 'empty' concept (as outlined by Swyngedouw) may represent marketing or commercialization techniques, which demonstrate the reasons behind it, the pursuit of an economic development at all costs and thence is a clear example of how the 'sustainable development' is used as a tool towards allowing the expansion of neoliberal policies sweeping through governments.

In this sense, much of the mainstream debate over sustainable development has ignored the cultural component, which Redclift (2005) signified as how needs are defined in different cultures. While conventional thinking considers sustainable development to be necessary for all of us, the analysis does not recognize that the concept could be defined in different ways with respect to each culture's own value system, not only in the social but also in the natural fields of thought.

Nowadays, we have an almost unified global economic system. A society lives in the developed world and is concerned with material wealth as its own basic need to be satisfied. It is obvious that this notion of need would differ dramatically from that of a society in a dependent country, which main goal is to subsist, and, therefore, its basic needs are fundamental to the needs of any living being: food and shelter.

Therefore, it is clear that societies define their 'needs' in ways that could preclude others from meeting their own (Redclift 2005 p.213-214), and, in the process, the long-term risks for the sustainability of other people's livelihoods could increase. However, it should be noted that the process through which some societies accrue their choices, thereby reducing those of others, is largely imperceptible to people in their daily lives. However, it is essential to understand it as a core issue for developing behaviour that could be considered sustainable.

Nevertheless, by ignoring the social and cultural differences that create a multi-layered grid of needs and goals specific to each culture, and by promoting consumerism as an ideal of progress, it is habitually supposed that the different societies around the globe are all pursuing the same goals. In this way, a lot of confusion has been generated regarding the question of what is to be sustained.

One thing is clear at present: the satisfaction of human needs is mostly operated and performed by transnational companies concerned only with the production-consumption cycles required to supply the satiation of global demand and (if possible) with expanding the markets. This desire for expansion is a response to the continual need for growth and expansion as one of the main features of the capitalist system, because it is the only way to widen the capital accumulation process towards its valorisation - the goal of which is to obtain increased levels of profit each time the cycle is fulfilled.

In order to have a clear understanding of the aforementioned capitalist cycle it would be necessary to cite Bellamy-Foster (2010) who stated that capitalism can be defined as a system of unsustainable development. He explains what Marx called 'simple commodity production', an idealized economic formation-often assumed to describe the society in which we live-wherein the structure of exchange is such that a commodity embodying a certain use value is exchanged for money (acting as a mere means of exchange), which is then, in turn, exchanged for another commodity (use value) in the end. Here, the whole exchange process from beginning to end can be designated by the shorthand C-M-C. In such a process, exchange is simply a modified form of barter, with money merely facilitating the exchange. The goal of exchange is concrete use values, embodying qualitative properties. Such use values are normally consumed, thereby bringing a given exchange process to an end. Foster proceeds to make clear the point that, according to Marx, a capitalist economy, in reality, works altogether differently, with exchange taking the form of $\mathrm{M}-\mathrm{C}-\mathrm{M}^{\prime}$. Here, money capital (M) is used to purchase commodities (labour power and means of production) in order to produce a commodity that can be ultimately sold for more money, $\mathrm{M}^{\prime}$ (i.e. $\mathrm{M}+\Delta \mathrm{m}$ or surplus value). This process, once set in motion, never stops of its own accord, since it has no natural end. Rather, the surplus value (profit) is reinvested in the next round, with the objective of generating $\mathrm{M}^{\prime \prime}$; in the following round, the returns are again reinvested with the goal of obtaining $\mathrm{M}^{\prime \prime \prime}$, and so on, ad infinitum.

The fact that this cycle has a direct relationship to the 'unsustainability' of the sustainable development concept must be outlined.

It is because of this logic of permanent (and apparently unstoppable) expansion that we are now witnessing increasing problems of pollution, erosion, desertification, global warming, over-exploitation, 
plundering, predation, and suppression of natural and human resources. All these factors are indeed considered 'undesirable consequences' for the majority of countries on the planet and are defined as goals to be eradicated and suppressed in many international agreements, though they are simultaneously prerequisites for the proper establishment and reproduction of capitalist relations. Therefore, it could be assumed that, in the methodological adjustment of the global production processes, the concept of sustainable development has turned out to be an economic, not simply an environmental, calculation.

The above-mentioned could be helpful towards understanding the ideological conception behind sustainable development, which, in this way, might not only preserve some fragments of nature, soothe some green consumers, or pay homage to the planet, but also enhance corporate profits, national productivity, and state power. For transnational corporations, obeying the sustainable development strategy is not a sacrifice, because it makes them apt to sustain development. In this sense, if being green, or at least greener, sells, then the rhetoric of 'sustainable development' could be used as a developmental strategy towards promoting a green commodification campaign. In so doing, through a green campaign, a marketing firm creates green advertisements and propagates them through the appropriate media, thereby creating a niche market. Then (once these new consumers have been identified), the green consumer goods can be supplied in order to fulfil their needs; it must be underscored that the fulfilment of these needs will be met by global capital.

As Baudrillard observes,

"The consumption of individuals mediates the productivity of corporate capital; it becomes a productive force required by the functioning of the system itself, by its process of reproduction and survival. In other words, there are these kinds of needs because the system of corporate production needs them. And the needs invested by the individual consumer today are just as essential to the order of production as the capital invested by the capitalist entrepreneur and the labour power invested in the wage labourer. It is all capital.” (1981, p82)

The transformation of the capitalist system of production accumulation has generated a very specific kind of society and discourse, in which consumption is one of the main mechanisms of social integration (Ewen, 1988). These relations of power are strategic and diffuse.

The consumers are not only a raw material to be colonized and disciplined by the social order, but also one of the resources that reaffirm it, express it, and reproduce it. "The individual is formed from a series of processes and systems which do not respond to a nature... but obey historical, political, and social conditions" (Castro, 2006, p173). And in today's consumer society, green discursive practices are closely linked to the stimulation of being connected to the earth by buying some specific type of green product.

In this sense, we are cultivating the concept of consumer society, wherein needs are no longer vital, but they are instead imposed. In this vein, the needs of the individual have changed because this individual does not only have the need to eat, but (in connection with that) he also has the need to eat organic or green products. This is because the action rearranges and readjusts itself in the function of the productive system's exigencies.

"If the problem of bad equilibrium established in previous centuries was to produce enough to meet needs, the new problem consists of creating the need to consume what is produced" (Salvat, 1975, p32). Using this logic, consumerism seeks to represent the postmodern form of freedom (Rojas, 1992), in which the individual believes that he acts freely, but his independence often clashes with the prohibitions set for coexistence.

Luke (2005, p238) asserts additionally that the consumer is not docile, (s)he is an active, erratic, and capricious supporter of every unsustainably developed circuit of corporate globalism's power and its effects, and must be captured and convinced of the merits of each commodification campaign. In this way when a rhetoric of sustainable development takes root, consumers want to believe that buying the right stuff gets them 'reconnected' to the planet, so one must recognize how individual subjects often struggle to reposition by their possessions in the manifold agendas of a green transnational globalism.

It should be emphasized that these kinds of needs are always manipulated to reach the condition of being transcendent, showing consumption as the route towards achieving perfection, self-esteem, social success, and, lately, a definitive way to re-connect with the planet, as well as to nurture it.

Foucault states that the analysis of a discourse is the attempt to reach the network of structures that conforms to it in order to see the moment when the elements begin to unravel, to see those that are missing and present, their locations and meanings, and to seek the relationship between the subject, his/her discourse, and the larger social discourse. Thus, the work, production, and consumption put at stake a quest for the construction of a kind of subjectivity, which is increasingly individualistic. Power operates here, not only to create, monitor, and normalize a mass of workers, but also to introduce and discipline consumers. There is a 'political anatomy' that is also a 'mechanic of power' [which] defines how to take hold 
of the body of the other, not just for them to do what you want, but to operate as is desired and according to the determined speed and efficiency" (Foucault, 1998, p141).

The sustained capacity to develop in a supposedly green way enters the battlefield at this point, when corporate ideologies of individual empowerment are reaffirmed with each act of personal-artefact appropriation as signs of, once more, backward markets attaining greater economic and social development. In this sense, the sustaining of the ability to further advance the prevailing mode of development is regarded as 'the best one can get' among the world's neoliberal programs for capitalist expansion. (Luke 2005, p. 234) Even when sustainable development is seen as the global goal, it is also true that many of the approaches to reach it have reconfigured the perception of reality in very intangible ways, and many of these perceptions have one thing in common: they consider things such as equality, distribution, and respect for nature simply as anachronisms opposed to the market.

\section{Final remarks}

\begin{abstract}
"The fantasy of imagining a nature which is benign and 'sustainable' avoids making a vital but politically sensitive question, about the type of solutions and assemblies that we want to produce, how can we achieve them and in what kind of environment we want to live, recognizing also the radical and undecidable contingency of Nature." (Swyngedouw, 2011, p41)
\end{abstract}

\begin{abstract}
"Although it is impossible to pinpoint exactly what does the term sustainability refers to (except in the most general or generic of terms, which allows the consensual use of the concept precisely because of its floating content), this meaning-emptiness is captured by a proliferating series of fantasies, stories and imaginations that try to fill the gap between the uncertainties of nature, and the fear associated with a continuous return of the 'Real-nature' in form of ecological disasters like droughts , hurricanes , floods, etc." (Ibid.)
\end{abstract}

This is the clearest expression of the imaginary order (which is constituted in a process that requires a certain degree of structural alienation), considering it from the Lacanian perspective.

In this sense, Marx believed that most of what men thought consciously, was false consciousness, ideology and rationalization, and that the true sources of human acts were unconscious. According to Marx human acts are originated in the whole social organization, which directs its consciousness in specific directions though preventing him to be aware of certain facts and experiences.
"The mode of production of material life conditions the general process of social, political and intellectual life. It is not the consciousness of men that determines their existence, but their social existence that determines their consciousness. Just as one does not judge an individual by what he thinks about himself, so one cannot judge such a period of transformation by its consciousness, but, on the contrary, this consciousness must be explained from the contradictions of material life, from the conflict existing between the social forces of production and the relations of production."

(Marx, 1859, p4)

Regarding this issue I would like to outline the old phrase, which states that history is written by the victors, it must be remarked that for quite some time now, the history of the neoliberalism and the sustainable development is being written by the losers, and from that standpoint this paper attempts to contribute to the critical thinking from an analysis of the hegemonic neoliberal ideology, which supports the idea of the end of history and the technocratic universalism which in turn implies the imposition of a single model of life, denying, in the name of realism and the end of utopias, any other alternative possibility.

This makes it necessary to recover the critical thinking to analyse and understand the reality, thus overcoming the ideological barrier towards claiming that things can be otherwise. This statement could be considered utopic, since what's the case in overcoming the ideological barrier and understand the reality if there is nothing to be done against the dismantlement of the neoliberal superstructure, which is supported by the institutions in charge of the global economy and besides that, is also well established all around the globe?

It must be remarked that an utopic alternative is needed as standpoint to realize that what's given is not the only possibility. "We need to radicalize the imaginary as an antidote to the total imposition of neoliberal technocratism in the common sense." (Lander, 1971)

In this direction, David Harvey stated:

"I think that there is always the need to have in mind an
utopic vision, (...) a place that we want to reach, where
we want to be, even if in the end we don't reach it, in a
certain sense it does not really matter if we get there or
not. But if you have a vision, trying to move the things,
these things are moved in a direction or the other."
Harvey in (Boulet, 2013)

With this paper I hope to contribute to the analysis of the current phase of capitalism and the way in which its growth and expansion is maintained through a neoliberal ideology, which is in charge of soften domination by diffusing legitimating ideas and granting concessions to subordinate forces. 


\section{References}

Audi, R 1999, The Cambridge dictionary of philosophy, Cambridge University Press, Cambridge.

Baudrillard, J 1981, For a Critique of the Political Economy of the Sign, Telos, St. Louis.

Bellamy-Foster, J 2010, Warum der Kapitalismus ein System nicht nachhaltiger Entwicklung ist, Sozialistische Zeitung.

Boulet, E 2013, Le néolibéralisme comme "projet de classe", Entretien avec David Harvey, Contretemps.

Brenner, Peck \& Theodore 2011, ¿ ¿Y después de la neoliberalización? Estrategias metodológicas para la investigación de las transformaciones regulatorias contemporáneas'. Urban Nueva Serie - Los Futuros de la Planificación, o1.

Castro, R 2006,'Ética y Libertad: La pars construens de la filosofía foucaultiana', Revista de filosofía, pp. 62.

Chorev \& Babb 2009,'The crisis of neoliberalism and the future of international institutions: A comparison of the IMF and the WTO', Theory and Society: Renewal and Critique in Social Theory, pp. 459-484.

Corominas \& Pascual 2001, Diccionario crítico etimológico castellano e hispano, Gredos, Madrid.

Cox, R 2006,'Social forces, states, and world orders', in Little \& Smith (ed) Perspectives on World Politics, 3rd ed., Cambridge University Press, Cambridge.

Duménil \& Levy 2011, The crisis of neoliberalism, Harvard University Press, Cambridge, MA.

ECA 2011, Reform of the International Financial Architecture and the Policy Implications for Africa, Addis Ababa, UN.

Emberley \& Cooper 2004, Faith And Poltical Philosophy: The Correspondence between Leo Strauss and Eric Voegelin, 1934-1964, University of Missouri, Missouri.

Ewen, S 1988, All Consuming Images: The Politics of Style in Contemporary Culture, Basic Books, New York.

Foucault, M 1998, Vigilar y Castigar. El nacimiento de la prisión, Siglo Veintiuno, Mexico City.

Fuchs, C 2006,'The Dialectic of the Nature-Society-System', Triple C: Cognition, communication, cooperation, 4, pp. 139.
Fukuyama, F 1992, El fin de la historia y el último hombre, Planeta, Barcelona.

George \& Sabelli 1994, Faith and Credit: The World Bank's Secular Empire, Penguin Books, London.

Gill, S 1995,'Globalisation, Market Civilisation, and Disciplinary Neoliberalism', Millennium - Journal of International Studies, 24.

Goldman, M 2005, Imperial Nature: The World Bank and Struggles for Social Justice in the Age of Globalization, Yale University Press, New Haven.

Gramsci 1971, Selections from the prison notebooks, Lawrence and Wishart, London.

Harvey, D 2005, A Brief History of Neoliberalism, Oxford University Press, Oxford.

Lander, E 1971, Retos del pensamiento crítico latinoamericano en la década de los noventa' in E Lander (ed) Modernidad y universalismo, Nueva sociedad, Caracas.

Mardones \& Aguirre 1989, El hombre y la sociedad de consumo ante el juicio del evangelio, Editorial Sal Terrae, Bilbao.

Marx, K 1859, A contribution to the critique of political economy, Progress Publishers, Moscow.

Marx, K 1985, Das Kapital. Kritik der politischen Ökonomie, Dietz Verlag, Berlin.

Marx/Engels 1983, Marx-Engels-Werkausgabe (MEW) Band 42, Dietz, Berlin.

Prestowitz, C 2003, Rogue Nation, Basic Books, New York.

Redclift, M 2005,'Sustainable Development (1987-2005): An Oxymoron Comes of Age', Sustainable Development, pp. 212-227.

Rojas, E 1992, El hombre light: Una vida sin valores, Planeta, Madrid.

Salvat, M 1975, La sociedad de consumo, Salvat, Barcelona.

Swyngedouw, E 2011, ¡La naturaleza no existe! La sostenibilidad como síntoma de una planificación despolitizada', Urban Nueva Serie - Los Futuros de la Planificación, 1.

Vergara, J 1984,'Popper y la teoría política neoliberal' in F Schuster (ed) Popper y las ciencias socials, Centro Editor de América Latina, Buenos Aires. 